\title{
Sense of humor in process of decision-making among students
}

\author{
Bilous R., Valverde Cota B., Braha S. \\ Kremenchuk Mikhailo Ostrogradskyi National University, Kremenchuk, Ukraine \\ University of Evora, Lisbon, Portugal
}

Received: $12.03 .2019 \quad$ Accepted: 14.04 .2019

\begin{abstract}
The article analyses the influence of sense of humor on decision-making among students. Analyses of constituents and stages of decision-making was performed. Main approaches to research of notion of decisionmaking, its particularities of forming among students were studied, and based on which the structure of decisionmaking was built. Meaning, components and psychological basis of researched notion of decision making were specified. Definition of "decision-making" is viewed as a necessary factor for self-realization, self-identification, selfhappening, self-improving and society useful activity, which is dedicated to the development of society and forming life strategy. Notion of "humor" is defined as a quality of action, language or piece of art, that provokes fun; ability to feel fun, gladness or its reflection; as a complex of positive emotions, important component of behavior, social relationship, life experience, higher quality of strategies for solving problematic situations; universal human activity, that is revealed in all elegeres of life. Importance of humor in life activity of a person is viewed. Main approaches to classifications of styles of humor are named. Psychological peculiarities of constructive humor usage in process of decision-making among students are researched. Results of performed research show that there is interconnection between styles of humor and strategies of decision-making. Gender differences in styles of humor are proven, as well as meaningful interconnection between style of humor, type of decision-making and a way of solving difficult situations among student are revealed. It is stated that affiliate, aggressive and self-not-respecting styles mostly provoke such decisions as intropunitive relation to the situation, narcotization, verbal aggression, aggression towards the objects, avoiding and procrastination. Results of research showed the usefulness to apply self-supporting style of humor for more rational ways of decision-making.
\end{abstract}

Key words: humor, styles of humor, student age, decision-making, strategies of decision-making, emotional sphere.

\section{Почуття гумору у процесі прийняття рішень студентами \\ Білоус Р. М., Валверде Кота Б., Брага С. Ю. \\ Кременчуцький національний університет імені Михайла Остроградського, Кременчук, Україна Університет Евора, Лісабон, Португалія}

\begin{abstract}
Анотація. У стапті було проаналізовано питання впливу почуття гумору на прийняття рішень студентами. Зроблено аналіз складових та основних етапів прийняття рішень студентами. Досліджено основні теоретичні підходи щодо вивчення проблеми прийняття рішень та закономірності ї̈ формування у студентів, на основі яких побудовано структуру прийняптя рішень. Уточнено зміст, компоненти та психологічну сутність досліджуваного феномена прийнятяя рішень. Розглянута дефініція «прийняття рішення» як необхідний фрактор самореалізації, самоідентифікації, самоздійснення, самовдосконалення та суспільно корисної діяльності, яка спрямована на розвиток суспільства та формування життєвої стратегї. Визначено поняття «гумору» як якість дії, мови або художнього твору, що провокує веселощі; здатність сприйняття смішного, веселого або його відтворення; як комплекс позитивних емоцій, важлива складова поведінки, суспільних відносин, життєвого досвіду, підвищена якість стратегій вирішення проблемних ситуацій; універсальна людська активність, яка проявляється в усіх ссрерах життя. Розглянуто значення почуття гумору в життєдіяльності людини. Названо основні підходи до класифікації стилів гумору. Досліджено психологічні особливості конструктивних проявів гумору у процесі прийняття рішень студентами. Результати проведеного емпіричного дослідження свідчать про наявність взаємозв'язку стилів гумору із стратегіями прийняття рішень. Доведено наявність статевих відмінностей стилів гумору, а також виявлено значущі взаємозв'язки між стилем
\end{abstract}

\footnotetext{
Corresponding Author: Bilous Ruslana. Tel. +38(066) 11-55-797. E-mail: bilousru63@xgmail.com Kremenchuk Mykhailo Ostrohradskyi National University, vul.Pershotravneva, 20, Kremenchuk, Poltava Region, Ukraine, 39600

Відповідальний автор: Білоус Руслана Миколаївна +38(066)11-55-797. E-mail: bilousru63@xgmail.com Кременчуцький національний університет імені Михайла Остроградського, вул. Першотравнева, 20, м. Кременчук Полтавської обл., Україна, 39600.
} 
гумору, типом прийняття рішень та способом вирішення складних ситуацій у студентському віці. Констатовано, що афіліативний, агресивний та самозневажливий стилі гумору провокують у більшості випадків такі типи прийняття рішення, як інтрапунітивне відношення до ситуації, наркотизацію, вербальну агресію, агресію до предметів, уникнення та прокрастинацію. Результати дослідження показали доцільність використання самопідтримуючого стилю гумору для більш раціональних способів прийняття рішень.

Ключові слова: гумор, стилі гумору, студентський вік, прийняття рішень, стратегії прийняття рішень, емоційна сфера.

\title{
Чувство юмора в процессе принятия решений студентами
}

\author{
Белоус Р. Н., Валверде Кота Б., Брага С. Ю. \\ Кременчугский национальный университет имени Михаила Остроградского \\ Университет Евора, Лиссабон, Португалия
}

\begin{abstract}
Аннотация. В статье был проанализирован вопрос влияния чувства юмора на принятие решений студентами. Сделан анализ составляющих и этапов принятий решений студентами. Исследованы основные подходы изучения проблемы принятия решений и закономерности её формирования у студентов, на основе которых построено структуру принятия решений. Уточнено содержание, компоненты и психологическую сущность исследуемого феномена принятия решений. Рассмотрена дефиниция «принятие решений» как необходимый фактор самореализации, самоидентификации, самоусовершенствования и общественно полезной деятельности, которая направлена на развитие общества и формирование жизненной стратегии. Определено понятие «юмор» как качество действия, речи или художественного произведения, провоцирующая веселье; способность к восприятию смешного, веселого или его воспроизведению; как комплекс положительных эмоций, важная составляющая поведения, общественных отношений, жизненного опыта, повышенное качество стратегий решения проблемных ситуаций; универсальная человеческая активность, которая проявляется во всех сферах жизни. Рассмотрено значение юмора в жизнедеятельности человека. Названы основные подходы классификации стилей юмора. Исследованы психологические особенности конструктивных проявлений юмора в процессе принятия решений студентами. Результаты проведённого исследования свидетельствуют о наличии взаимосвязи стилей юмора со стратегиями принятия решений. Доказано наличие половых различий стилей юмора, а также выявлено значительные взаимосвязи между стилем юмора, типом принятия решений и способом решения сложных ситуаций у студентов. Констатировано, что аффрилиативный, агрессивный и самоуничижительный стили провоцируют в большинстве случаев такие решения, как интрапунитивное отношение к ситуации, наркотизацию, вербальную агрессию, агрессию к предметам, избегание и прокрастинацию. Результаты исследования показали целесообразность использования самоподдерживающего стиля юмора для более рациональных способов принятия решений.
\end{abstract}

Ключевые слова: юмор, стили юмора, студенческий возраст, принятие решений, стратегии принятия решений, эмоциональная сфера.

\section{Bcmyn}

Необхідність виваженого адекватного вибору з різноманітних альтернатив актуалізує проблему прийняття рішень для сучасної людини. Прийняття рішення - це, передусім, особистісний вибір із альтернативних, можливих варіантів, детермінований психологічною організацією особистості, за участі різнорівневих іï характеристик і в той же час відображаючих цілісність особистості. Вступаючи у доросле життя, юнаки відходять від опіки батьків, починають самостійно планувати своє майбутнє життя, тому саме у студентському віці проблема прийняття рішень $є$ однією із найважливіших. Саме почуття гумору, як комплекс позитивних емоцій, важлива складова поведінки, суспільних відносин, дозволяє стимулювати процеси мислення для подолання спричинених недостатністю досвіду труднощів.

Проблемою прийняття рішень як необхідного фактору самореалізації, самоідентифікації та саморегуляції, спрямованої на побудову життєвої стратегії, займалися А. Кабиш-Рибалка, М. Рева, О. Санніков, І. Тичина, Н.Фалько. Дослідженням особливостей вираження гумору займалися А. Бабаджанова, О. Грицук, І. Домбровська, Х. Іванова, Г. Карпенко, О. Зайва та ін.

Метою статmі $\epsilon$ дослідження впливу гумору на процес прийняття рішень студентами. 


\section{II Матеріал і методи дослідження}

Проблема прийняття рішень розглядається у роботах низки дослідників. В. Джеймс указував на зумовленість вибору розумом, імпульсом, волею та виділяв п'ять видів рішень: розумне, в якому людина вибирає альтернативу і провокує почуття свободи; вольове, що зосереджує увагу на глибинному відчутті «внутрішнього зусилля»; дрейфуюче (кожен аргумент на користь певного вибору призводить до почуття розчарування і втоми); імпульсивне (випадкове) та рішення, зумовлене зміною кута зору, яке $є$ наслідком досвіду чи емоційного стану.

Ф. Достоєвський пов'язував процес прийняття рішень, передусім, 3 моральною сферою особистості, її духовністю, світоглядними характеристиками, ідеалами, смислами та цінностями, що розглядається в координатах інтелекту й емоцій, актуалізуючи вищі психічні функції особистості. Прийняття рішень через вибір відображено в психологічній теорії поля К. Левіна, яка розкриває авторську методологію аналізу життєвого простору людини та групи, при цьому особливу роль у прийнятті рішень виконує такий конструкт як валентність.

П. Анохін підкреслював, що прийняття рішення - процес, що включає різні рівні організації: від окремого нейрона, який продукує свою відповідь у результаті синтезу багатьох впливів, до системи в цілому, інтегруючий вплив багатьох нейрональних об'єднань. Остаточний результат процесу виражається в твердженні: система прийняла рішення [1].

На думку К. Абульханової-Славської, важливу роль у прийнятті людиною рішень відіграє соціальне мислення, яке допомагає розширити світогляд та знайти альтернативні варіанти [2]. Г. Балл наголошує на важливості актів вибору у процесі прийняття й реалізації особою стратегічно-життєвих рішень, зумовлених соціальними нормами, регулюючими людську поведінку, вибором між альтернативами [3]. Проте інколи прийняття рішення $є$ проявом креативності, знаходженням нових шляхів вирішення проблеми, адже життя (за Л. Сохань), вимагаюче прийняття рішень, це творчий процес розробки, зміни та здійснення людиною власного життєвого сценарію.

Ю. Швалб розробив концепцію цілепокладання як регулятивної основи навчальної діяльності. Конкретизуючи основні положення Ю. Швалба, В. Чернобровкін започаткував підхід до аналізу причинності процесу прийняття рішень учителем у проблемних ситуаціях, методологічно обгрунтувавши визначення понять «поведінка вчителя» та «педагогічна діяльність».

Досліджуючи взаємозв'язок прийняття рішення з психологічним віком Т. Титаренко зазначає , що усвідомлене ставлення до свого минулого, теперішнього і майбутнього стимулює пошук конструктивних рішень, визначаючи поведінку людини. Життєвий шлях (І. Єрмаков, В. Нечипуренко, Д. Пузиков) є формою індивідуального становлення і розвитку, у якій додатково формується відношення до себе, до свого життя, утворюючи життєву стратегію особистості. На думку Л. Веккера, довільні рішення можуть бути виражені тільки у подіях, по відношенню до яких відповідні дії або вчинки відбуваються. Л. Виготський вбачав у виборі ядро вольового акту, а І. Бех акцентує важливу роль волі в прийнятті рішення [4]. Г. Шварц вважав, що прийняття рішення - свідомий процес, який передбачає попереднє чітке усвідомлення мети, структурування вихідної проблемної ситуації, вибір найкращої альтернативи 3 використанням певних методів.

В. Ямницький акцентує увагу на понятті життєвого потенціалу, досліджуючи активність особистості. Вміння добре орієнтуватися у нестандартних ситуаціях життя, обирати неординарні рішення, знаходити шляхи виходу із кризової події та розв'язувати повсякденні проблеми, передбачаючи розроблення стратегії, планів і програми життя, - талант життєтворчості людини. В. Панок, Г. Рудь одним із найважливіших умінь у житті вважають вміння приймати рішення упродовж життя, адже саме це забезпечує перехід людини від минулого до майбутнього. В. Роменець розглядає прийняття рішення як складовий компонент принципу реалізації вчинку особистістю, а мотивацію, як конкретний психологічний механізм самоствердження. О. Тихомиров називає дві стадії прийняття рішення: знаходження принципу, ідеї і стадію перевірки чи реалізації знайденого.

В. Кушнір виділяє п'ять етапів прийняття рішення: процес цілеутворення; визначення значущості кожного критерію у вигляді вагових коефіцієнтів; оцінка інтенсивності критеріїв у вигляді числових значень; синтез; відображення різноманітних типів шкал на одну безрозмірну шкалу за допомогою 
психофрізичної функції оцінювання; синтез оцінок критеріїв за допомогою лінійних чи нелінійних функцій, метою якого є одержання нових знань про єдиний об'єкт.

Аналізуючи наведені психологами (Л. Манн, Я. Боукал) типи прийняття рішень, можна виділити конструктивні (механізми зниження психічної напруги, пильність, зростання зусиль до досягнення мети) та деструктивні (наркотизація, уникнення, зверхпильність, прокрастинація, порівняння своїх проблем 3 проблемами інших, вербальна агресія, агресія до людей, агресія до предметів, агресія до себе, інтрапунітивне відношення до ситуації, компенсація) типи прийняття рішень.

Д. Леонтьєв та М. Пилипко виокремлюють три типи вибору: простий як оптимальний варіант для досягнення певних результатів; смисловий вибір; особистісний вибір - самостійне конструювання альтернатив разом з майбутніми наслідками вибору конкретної з них із наступним аналізом можливих реалізацій обраної альтернативи для здійснення остаточного вибору.

Ю. Козелецький розглядає проблемні ситуації: ризиковані та закриті, що запускають процес прийняття рішень людиною. Закриті ситуації поділяються на прості, у яких кількість гіпотез про стан об'єкта від двох до шести, дорівнюючи кількості дій, та широкі - від шести до 10120. Всі вони запускають процес прийняття рішень людиною [5].

Досліджуючи феномен гумору, можна визначити спільні для усіх підходів ознаки: когнітивні процеси, емоційне переживання насолоди від гумористичних інтервенцій, поведінкові реакції, які проявляються в індивідуальному стилі реагування. Також можна виділити два основних підходи до вивчення почуття гумору, як універсальної людської характеристики. У першому випадку його розглядають як здібність, пов'язану з особливостями мислення і побудови когнітивної сфери, тоді увага звертається на взаємодії за участі гумору, стильові характеристики, установки по відношенню до різноманітних ситуацій. У другому випадку існують дослідження, де почуття гумору розглядається як властивість, риса або якість особистості, в першу чергу, пов'язана з особливостями емоційних реакцій.

Р. Мартін зробив висновок щодо наявності чотирьох основних варіантів використання гумору: двох конструктивних (афіліативний та самопідтримуючий) та двох неконструктивних (агресивний і самозневажливий). Афіліативний гумор пов'язаний з екстраверсією, відкритістю новому досвіду, само прийняттям, успішністю встановлення та підтримання міжособистісних стосунків, задоволеністю життям та переважанням позитивних емоцій. Самопідтримуючий стиль гумору включає позитивний погляд на життя, є регулятором емоцій і механізмом подолання стресу. Люди з агресивним стилем гумору можуть використовувати сарказм та насмішки, застосовувати із ціллю маніпуляцій іншими. Даний стиль гумору корелює із нейротизмом, ворожістю, гнівом і агресією. Самозневажливий стиль гумору направлений проти самого себе, з ціллю завоювання уваги авторитетних осіб (використовують себе як об'єкт жартів) [6].

За В. Франклом, гумор дозволяє людині створити дистанцію між нею і ситуацією, в якій вона знаходиться, для управління нею хоча $б$ у ментальному просторі. Автор довів сутність гумору як важливого захисного механізму, підпорядкованого свідомості, виникаючого на основі процесів мислення людини. Є. Ільїн відносив гумор до інтелектуальної характеристики людини; установки, сприяючої виникненню веселощів [7].

У молоді функцією гумору є доречне вираження агресії, встановлення контактів, перевірка свого статусу; у дорослих людей він спрямований на подолання стресових ситуацій та підтримку позитивного бачення світу. Б. Фредріксон та Р. Левенсон експериментально довели користь позитивних емоцій (через їх стимуляцію), що веде до зниження фрізіологічного збудження. Б. Фредріксон розробила модель «розширюй та створюй» для опису функцій радості: розширення меж фокусу уваги (веде до творчого рішення проблем та збільшення варіантів поведінкових реакцій, прийняття рішень), створення ресурсів для життєвого розвитку, посилення адаптаційних можливостей, підвищення фізичного та психічного самопочуття. Таким чином, при високому рівні гумору у студентів прослідковуються: висока гнучкість мислення, планування, пошук альтернатив, більш високий рівень креативності та аналітичності мислення.

Отже, гумор - це провокуюча веселощі якість дії (мови); здатність відтворення та сприймання кумедних співвідношень дійсності; форма соціальної гри для отримання емоційної насолоди; непряма передача неявних сигналів; захист від одноманітності культури. Почуття гумору пов'язується з рівнем 
аналітичного мислення особистості, з її схильністю жартувати, сміятися над гумором інших, здатністю помічати в явищах комічні сторони, виявляти протиріччя у навколишній дійсності.

У ході емпіричного дослідження впливу гумору на прийняття рішень студентами було використано: спостереження за поведінкою респондентів у ході дослідження, бесіда для пояснення процедури експерименту та психологічне тестування: опитувальник для діагностики індивідуального стилю прийняття рішень (МОПР); опитувальник «Рішення важких ситуацій» для виявлення основного типу рішення важких ситуацій; «Опитувальник стилів гумору» для встановлення домінуючого стилю гумору: афріліативного, самопідтримуючого, агресивного чи самозневажливого.

Емпіричне дослідження впливу почуття гумору на прийняття рішень у студентів проводилося на базі Кременчуцького національного університету імені Михайла Остроградського серед студентів IV курсу. Вибірка дослідження гомогенна за віковою категорією (студентський вік), загальна кількість респондентів - 59 осіб (студентів факультету електроніки та комп'ютерної інженерії), серед яких 30 юнаків та 29 дівчат.

\section{III Результати}

У ході дослідження отримано такі результати: у студентів наявні наступні стратегії прийняття рішень - пильність (76 \%), уникнення (14\%), прокрастинація (7\%) та зверхпильність (3 \%). У важких ситуаціях спостерігаються тенденція зростання зусиль задля досягнення мети, інтрапунітивне відношення до ситуації, наркотизація, вербальна агресія, компенсація та порівняння своїх проблем 3 проблемами інших, механізм зниження психічної напруги та агресія до предметів.

Студенти з афіліативним стилем гумору у важких ситуаціях виявляють зростання зусиль задля досягнення мети (29\%), у них виникає агресія до предметів (29\%), вони порівнюють свої проблеми 3 проблемами інших (18\%), демонструють вербальну агресію (12\%) та можуть стимулювати себе вживанням сигарет, алкоголю та ліків (12\%), при цьому зустрічаються такі типи прийняття рішень як пильність (74\%), ухилення та зверхпильність (по $13 \%$ ).

У респондентів із самопідтримуючим стилем гумору при рішенні важких ситуацій зростають зусилля задля досягнення мети (85\%) та проявляються пильність (90\%), прокрастинація (5\%), зверхпильність (5\%). При агресивному стилі діагностовано зростання зусиль задля досягнення мети (24\%), наркотизацію (23\%), вербальну агресію (23\%), механізм зниження психічної напруги (15\%), компенсацію (15\%), та типи прийняття рішень: пильність (64\%), уникнення (14\%), прокрастинацію $(22 \%)$.

У студентів із самозневажливим стилем гумору при прийнятті рішень спостерігаються інтрапунітивне відношення до ситуації (78 \%), механізм зниження психічної напруги (11 \%) та компенсація (11\%); вони використовують пильність (78 \%), уникнення (11\%) та прокрастинацію (11\%).

Для розвитку почуття гумору у студентів застосовують методи цілеспрямованого психологічного впливу, особливо ефективним $€$ соціально-психологічний тренінг як групова фрорма діяльності. Програма соціально-психологічного тренінгу «Розвиток самопідтримуючого стилю гумору та позитивного погляду на життя» включає в себе рольові ігри, моделювання ситуацій, вправи на активізацію, інфрормаційні повідомлення, мозковий штурм.

Враховуючи вище зазначене, основними принципами, дотримання яких сприяє підвищенню результативності реалізації програми є: діалогізація взаємодії, заснована на довірі, толерантності та рівноправності у міжособистісній взаємодії учасників; добровільна й активна участь у тренінгових заняттях - ініціативність, зацікавленість студентів при виконанні вправ та обговоренні проблемних питань, висловлювання власної думки, ставлення до проблеми тощо; зворотній зв'язок - отримання інформації про результати, оптимальність, доцільність своєї поведінки та діяльності тренера і членів групи;самодіагностика - усвідомлення, розкриття учасниками власних здібностей та можливостей, відкритт я невідомих аспектів власного «Я», формулювання особистісних проблем;включеність занурення у проблематику заняття, що вимагає організації роботи протягом досить тривалого часу; гармонізація інтелектуальної та емоційної сфер; забезпечення конфіденційності занять.

Програма містить вправи, які передбачають наявність глибоких рефлексивних компонентів, отримання зворотного зв'язку, бурхливих емоційних переживань. Актуальність тренінгу полягає у підвищенні впевненості у собі та усвідомленні власних мотивів, що сприяє покращенню перебігу 
вольових процесів; полегшенню контакту і взаємодії з іншими людьми, розвитку інтелектуальної розкутості, гнучкості мислення, вербального інтелекту; тренування навичок переговорів; розвиток дотепності, креативності.

\section{IV Обговорення}

Актуальність проблеми дослідження почуття гумору у процесі прийняття рішень студентами підтверджується рядом публікацій. Зокрема, О. Санніков у дослідженні [8] розглядає поняття «рішення» не тільки як явище або інтегральний психічний процес, але й результат вибору цілі, формування й реалізація програми дій, використання способу отримання або стратегії прийняття рішення. Автор зазначає, що саме готовність до ризику, як особистісна властивість до саморегуляції, забезпечує можливість особистості приймати рішення і активно діяти в нестабільних умовах сучасного суспільства [9]. Крім того, виокремлено наступні компоненти в структурі прийняття життєвих рішень: суб'єкт вибору (особистість, суб'єкт або група суб'єктів життєдіяльності); об'єкт вибору (мотив, вчинок, дія або система дій), які піддаються впливу рішення, прийнятого суб'єктом вибору; фрактори вибору (умови життєдіяльності, обставини, причини, які викликають у суб'єкта занепокоєння та створюють ситуацію вибору) [10].

Як стверджує І. Галян, самореалізації особистості у студентському віці сприяють ціннісні орієнтації, серед них - висока мотивація, спрямованість особистості на досягнення максимального результату, творче ставлення до професійної діяльності, реалізація своїх здібностей, що потребує вдосконалення процесу прийняття рішень [11]. Н. Чепелєва розглядає самопроектування як здатність особистості приймати рішення та діяти, виходячи з власного задуму, проекту відносно свого майбутнього (життєвий проект) та власної особистості (особистісний проект) [12]. А. Курова вважає самоефективність особистості характеристикою самосвідомості, яка представляє собою єдність процесів самопізнання, самооцінювання, самоставлення, саморегулювання та Я-концепції, що забезпечує життєстійкість особистості та розвиває їі часову перспективу [13]. М. Рева відзначає, що есрективне життєве цілепокладання визначається високим рівнем усвідомлення цілей, розгорнутістю у просторі, поєднанням глобальної, віддаленої і короткочасної часових перспектив, узгодженістю, логічністю та реалістичністю цілей, позитивним ставленням до майбутнього, достатнім усвідомленням чинників, які впливають на прийняття життєво важливих рішень [14].

Дослідження Ю. Сербіна показує, що у мотиваційній структурі студентів переважають мотиви, пов'язані 3 професійною самореалізацією, які особливо значущі для студентів старших курсів, спонукаючи до прийняття рішень, пов'язаних із близькими професійними цілями [15]. А. Кабиш-Рибалка вважає, що студентський період у житті людини є одним із потенційно найсприятливіших для прийняття рішень, пов'язаних із проектуванням стратегій життєвого шляху [16]. Н. Фалько визначає основні напрями діяльності, що орієнтують на підготовку майбутніх фрахівців до проектування та реалізації життєвих стратегій: формування сенсожиттєвих настанов через визначення сенсу власного життя та своєї життєвої стратегії [17].

Досліджуючи феномен почуття гумору, X. Іванова виявила, що яскравим сенситивним періодом емоційного життєвого досвіду виступає саме юнацький вік, адже саме в ньому людина розкриває свій потенціал та набуває багатий життєвий досвід, в якому гумор може виступати важливою особливістю в процесі становлення позитивного погляду на життя, сприяючи розвитку оптимістично налаштованої особистості [18]. С. Дворянчикова вказує на доцільність використання гумористичних текстів задля полегшення засвоєння матеріалу студентами, активізації їх самостійності та пізнавальної активності, розвитку креативності у вигляді прийняття нестандартних рішень [19]. Отже, можна дійти до висновку, що гумор - універсальна людська активність, яка проявляється в усіх сфрерах життя. 3 психологічної точки зору, гумор розглядається як позитивна емоція, котру в соціальних контекстах провокує процес оцінки несерйозної невідповідності; спосіб комунікації, передачі непрямої інформації.

Узагальнення наведених точок зору щодо прийняття рішення дозволяє визначити його структуру: усвідомлення типу ситуації (відкрита, проблемна, ризикована чи закрита), оцінка ситуації (для подальшого їі аналізу), усвідомлення проблеми (розуміння реального становища), пошук альтернатив та їх оцінка (аналіз знайдених варіантів дії, рішень), вибір подальшої дії (захисне ухилення, гіперреакція чи зверхпильність) та власне реалізація (рис.1). 


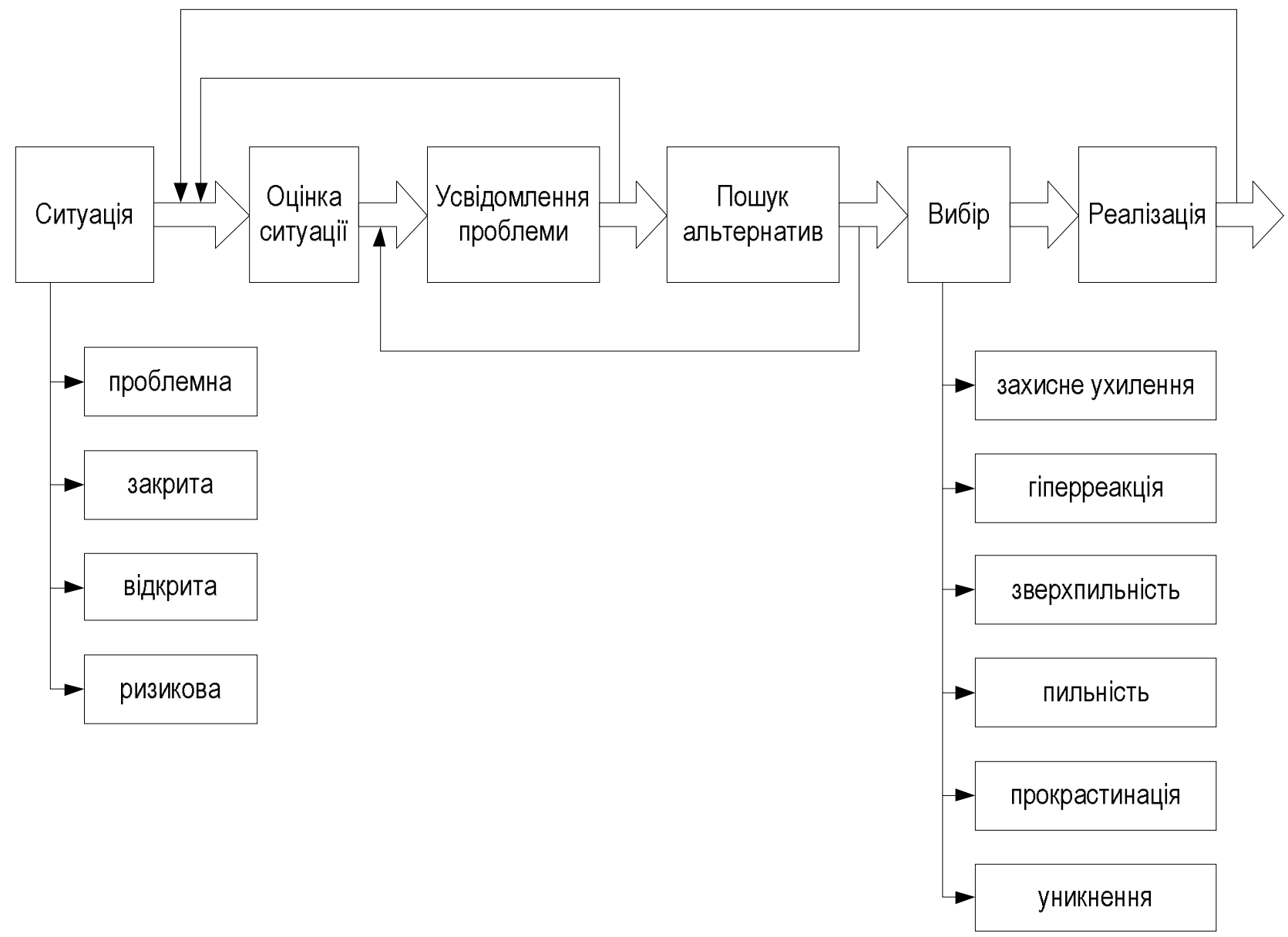

Рис. 1. Структура процесу прийняття рішення особистістю

Прийняття рішення формується, проявляється і реалізується на двох основних рівнях, що схематично зображені на рис. 2.

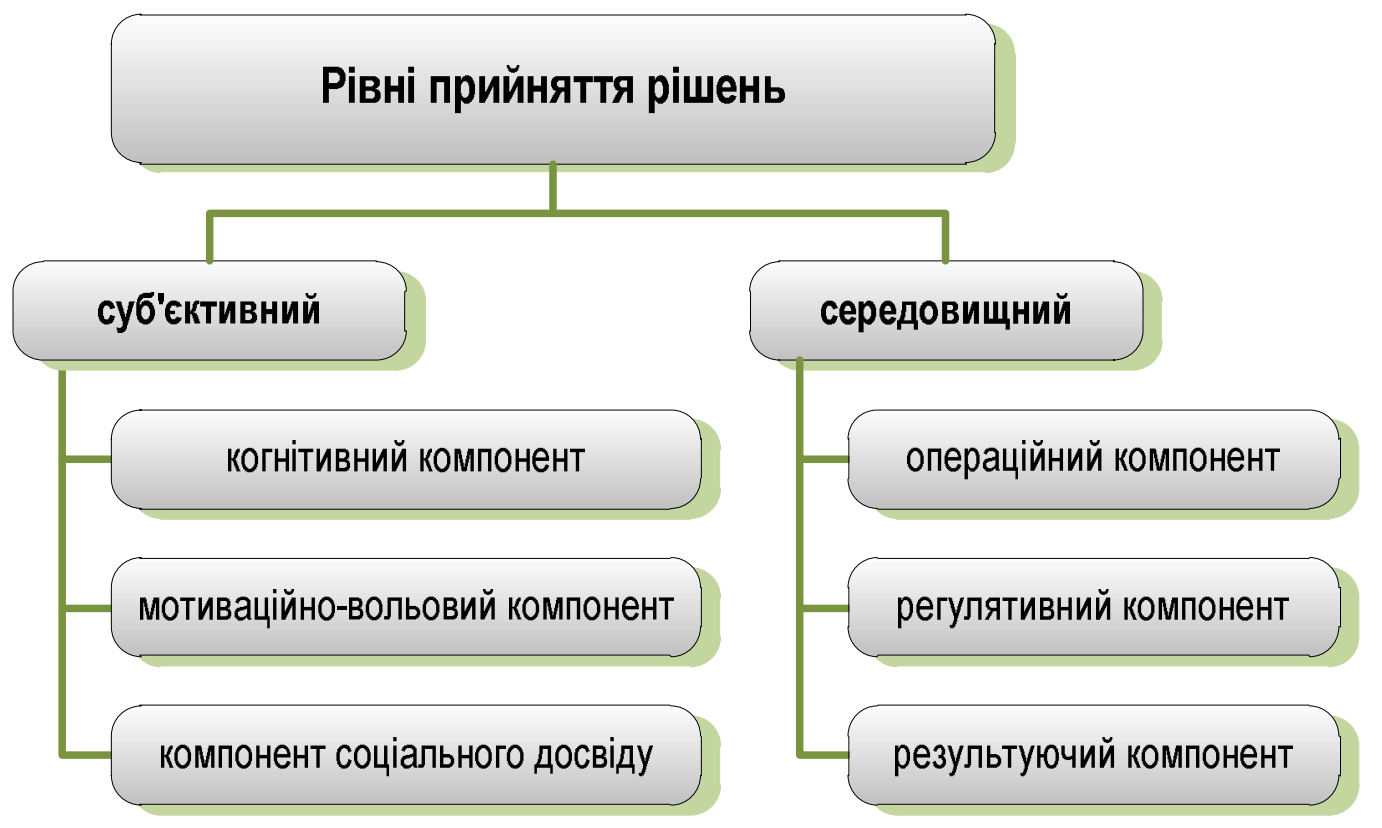

Рис. 2. Рівні прийняття рішень 
Таким чином, процес прийняття рішень особистістю є поетапним (рис. 1): розуміння типу ситуації (відкрита, проблемна, ризикована чи закрита), оцінка ситуації (для подальшого її аналізу), усвідомлення проблеми (розуміння реального становища), пошук альтернатив та їх оцінка (аналіз знайдених варіантів дії, рішень), вибір подальшої дії (захисне ухилення, гіперреакція, пильність, зверхпильність, прокрастинація чи уникнення) та власне реалізацію.

\section{V Висновки}

Таким чином, процес прийняття рішень являє собою складну структуру зі своїми особливостями; це етап вольового процесу, який починається з пошуку та порівняння альтернативних варіантів, вибору найкращого варіанту, що завершується побудовою дій, реалізацією знайденого способу; показник високого ступеня розвитку та розуміння, необхідний чинник індивідуального стилю у пізнавальній діяльності особистості. За результатами емпіричного дослідження можна констатувати, що при самопідтримуючому стилі гумору використовується більш раціональний спосіб прийняття рішень, зростають зусилля до досягнення мети. Афріліативний, агресивний та самозневажливий стилі провокують у більшості випадків такі рішення як інтрапунітивне відношення до ситуації, наркотизацію, вербальну агресію, агресію до предметів, уникнення та прокрастинацію.

Перспективними напрямами подальших досліджень $\epsilon$ вивчення гендерних та вікових особливостей почуття гумору у людей з психічними захворюваннями; вплив стилів гумору на інтелектуальні здібності; взаємозв'язок почуття гумору та рівня ораторських здібностей.

\section{Бібліографрічні посилання}

[1] Анохин П. К. Проблема принятия решений в психологии и психофизиологии. Москва : Наука, 1976. 319 c.

[2] Абульханова-Славская К. А. Стратегия жизни. Москва : Мысль, 1991. 299 с.

[3] Балл Г. О. Феномен вибору в контексті соціальної поведінки. Соц. психологія. 2005. № 1. С. 3-13.

[4] Выготский Л. С. Инструментальный метод в психологии. Москва : Педагогика, 1982. 108 с.

[5] Козелецкий Ю. Психологическая теория решений. Москва : Прогресс, 1979. 504 с.

[6] Мартин Р. Психология юмора. Санкт-Петербург : Питер, 2009. 480 c.

[7] Frankl Victor E. Man's Search for Meaning. New York : Washington Square Press, 1985. $214 \mathrm{p}$

[8] Санніков О. І. Функціонально-інформаційний аналіз діяльності менеджера з персоналу. Матеріали II Всеукраїнського психологічного конгресу, присвяченого 110 річниці від дня народження Г. С. Костюка (19-20 квітня 2010 року). Київ : ДП «Інформаційно-аналітичне агентство», 2010. С. 399-403.

[9] Санников А. И. Мотивация и побуждение в исследованиях принятия решений. Наука і освіта. 2014. № 11/CXXVIII. С. 190-197.

[10] Санников А. И. Личностные предикторы принятия жизненных решений. Наука і освіта. 2015. № 10/CXXXIX. С. 217-230.

[11] Галян І. М. Ціннісно-смислова саморегуляція особистості: ґенеза та механізми функціонування : монографія. Дрогобич : Редакційно-видавничий відділ ДДПУ імені Івана Франка, 2016. 402 с.

[12] Чепелєва Н. В. Нормативна модель дискурсивного самопроектування особистості. Наука і освіта. 2017. № 11. С. $105-113$.

[13] Курова А. Особливості впливу часової перспективи на основні складові самоефективності. Наука і освіта. 2017. №11. C. 92-95.

[14] Рева М. Специфіка життєвого цілепокладання молоді у контексті прагнення до самореалізації. Наука і освіта. 2015. № 10. C. 104-110.

[15] Сербін Ю. Вплив особистісного адаптивного потенціалу студентів гуманітаріїв на процес їхньої адаптації до навчання. Наука і освіта. 2018. № 5-6. С. 19-25.

[16] Кабиш-Рибалка А. Життєві стратегії як творчі засоби проектування життєвого шляху особистості. Наука і освіта. 2016. № 5. C. 95-99.

[17] Falko N. M. Life strategy as a component in construction of the personality’s living space. Наука i освima. 2014. № 6. C. $114-117$.

[18] Іванова Х. Дослідження особливостей вираженості почуття гумору у студентів. Наука і освіта. 2015. № 7. С. 33-39.

[19] Дворянчикова С. Є. Поетика оніма в контексті комічних жанрів та сміхової культури : автореф. дис. на здобуття наук. ступеня канд. філол. наук : 10.02.15. Донецьк, 2014. 20 с. 


\section{References}

[1] Anokhyn, P.K. (1976). Problema prynyatyya reshenyy v psykholohyy y psykhofyzyolohyy [Problem of decision-making in psychology and psychopshysiology]. Nauka, Moscow, USSR, 319. [in Russian]

[2] Abul'khanova-Slavskaya, K. A. (1991). Stratehyya zhyzny [Strategy of life]. Mysl, Moscow, Russia, 299. [in Russian]

[3] Ball, H. O. (2005). Fenomen vyboru v konteksti sotsial'noyi povedinky [Phenomenon of choice in context of social behavior]. Sots. Psykholohiya [Social Psychology], 1, 3-13. [in Ukrainian]

[4] Vyhotskyy, L. S. (1982). Instrumental'nyy metod v psykholohyy [Instrumental method in psychology]. Pedahohyka, Moscow, USSR, 108. [in Russian]

[5] Kozeletskyy, Y. (1979). Psykholohycheskaya teoryya reshenyy [Psychological theory of decision]. Progress, Moscow, USSR, 504. [in Russian]

[6] Martyn, R. (2009). Psykholohyya yumora [Psychology of humor]. Piter, St-Petersburg, Russia, 480. [in Russian]

[7] Frankl, Victor E. (1985). Man's Search for Meaning. Washington Square Press, New York, USA, 214.

[8] Sannikov, O. I. (2010). Funkcionaljno-informacijnyj analiz dijaljnosti menedzhera z personalu. Materialy II Vseukrajinsjkogho psykhologhichnogho konghresu, prysvjachenogho 110 richnyci vid dnja narodzhennja Gh. S. Kostjuka (19-20 kvitnja 2010 roku) [Functional-informational analyses of activity of human-resources manager. Material of II All-Ukraininan psychological congress, devoted to the date of 110 commemoration of the birth of G.S.Kostuka (19-20 April 2010)]. Kyiv: DP «Informacijno-analitychne aghentstvo», 399-403. [in Ukrainian]

[9] Sannykov, A. Y. (2014). Motyvatsyya y pobuzhdenye v yssledovanyyakh prynyatyya reshenyy. [Motivation and awakening in research of decision-making]. Nauka i osvita [Science and education], 11/CXXVIII, 190-197. [in Russian]

[10] Sannykov, A.Y. (2015). Lychnostnye predyktory prynyatyya zhyznennykh reshenyy [Personal predictors of decision-making]. Nauka i osvita [Science and education], 10/CXXXIX, 217-230. [in Russian]

[11] Ghaljan, I. M. (2016). Cinnisno-smyslova samoreghuljacija osobystosti: geneza ta mekhanizmy funkcionuvannja : monoghrafija [Value-meaning self-regulation of personality: genesis and mechanism of functioning: monograph]. Droghobych : Redakcijno-vydavnychyj viddil DDPU imeni Ivana Franka, 402. [in Ukrainian]

[12] Chepeljeva, N. V. (2017). Normatyvna modelj dyskursyvnogho samoproektuvannja osobystosti [Normative model of discursive self-projection]. Nauka i osvita [Science and education], 11, 105-113. [in Ukrainian]

[13] Kurova, A. (2017). Osoblyvosti vplyvu chasovoji perspektyvy na osnovni skladovi samoefektyvnosti [Peculiarities of influence of time perspective on main constituents of self-effectiveness]. Nauka i osvita [Science and education], 11, 92-95.

[14] Reva, M. (2015). Specyfika zhyttjevogho cilepokladannja molodi u konteksti praghnennja do samorealizaciji [Peculiarity of life goal-definition of young people in context of aspiration for self-realization]. Nauka i osvita [Science and education], 10,. 104-110. [in Ukrainian]

[15] Serbin, Y. (2018). Vplyv osobystisnogho adaptyvnogho potencialu studentiv ghumanitarijiv na proces jikhnjoji adaptaciji do navchannja [Influence of personal adaptive potential of humanitarian students on the process of their adaptation to studying]. Nauka i osvita [Science and education], 5-6, 19-25. [in Ukrainian]

[16] Kabysh-Rybalka, A. (2016). Zhyttjevi strateghiji jak tvorchi zasoby proektuvannja zhyttjevogho shljakhu osobystosti [Life strategies as creative ways of projecting life way of personality]. Nauka i osvita [Science and education], 5, 95-99. [in Ukrainian]

[17] Falko, N. M. (2014). Life strategy as a component in construction of the personality`s living space. Nauka i osvita [Science and education], 6, 114-117.

[18] Ivanova, Kh. (2015). Doslidzhennja osoblyvostej vyrazhenosti pochuttja ghumoru u studentiv [Research of peculiarities of expressiveness of sense of humor among students]. Nauka i osvita [Science and education], 7, 33-39. [in Ukrainian]

[19] Dvorjanchykova, S. Je. (2014). Poetyka onima v konteksti komichnykh zhanriv ta smikhovoji kuljtury : avtoref. dys. na zdobuttja nauk. stupenja kand. filol. nauk : 10.02.15 [Poem poetry in context of comic genres and laughter culture: dissertation author's abstract for obtaining the degree of Candidate of Philological sciences: 10.02.15]. Donetsk, Ukraine, 20. [in Ukrainian]

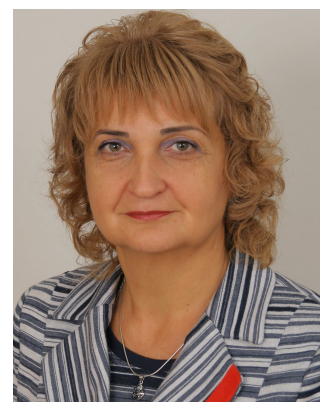

\section{Білоус Руслана Миколаївна.}

Кандидат психологічних наук, доцент, Завідувач кафедри психології, педагогіки та філософії. Кременчуцький національний університет імені Михайла Остроградського, вул. Першотравнева, 20, м. Кременчук Полтавської обл., Україна, 39614. Тел. +38(067)309-46-45. E-mail: bilousru63@gmail.com

\section{Bilous Ruslana Mykolaivna.}

Candidate of Psychological Sciences, Assistant Professor,

Head of a department of Psychology, pedagogics and philosophy

Kremenchuk Myhailo Ostrohradskyi National University,

vul. Pershotravneva, 20, Kremenchuk, Poltava Region, Ukraine, 39614.

Tel.: +38(067)309-46-45. E-mail: bilousru63@gmail.com

ORCID: 0000-0003-3524-7823

Researcher ID: U-6232-2017 


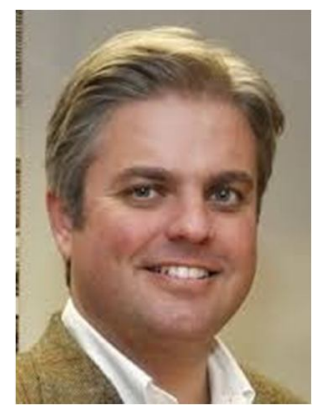

Бруно Валверде Кота.

Доктор наук з управління, спеціальність маркетинг, університета Евора, Португалія, Запрошений професор бізнес школи Католіка Порто, Португалія,

член Наукової поради Вищого інституту Управління Банковською справою, Лісабон, Португалія.

Тел 00351215970088. E-mail cota.bruno@gmail.com

\section{Bruno Valverde Cota}

$\mathrm{PhD}$ in Management, specialty of Marketing of University of Evora, Portugal, Invited associate professor of Catolica Porto Business School, Porto, Portugal,

Member of Scientific Council of The Portuguese School of Bank Management, Lisbon, Portugal

Tel.: 00351215970088 . E-mail cota.bruno@gmail.com

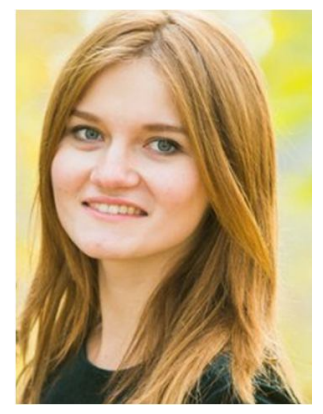

\section{Брага Світлана Юріївна.}

Студентка 3 курсу, спеціальність «Психологія», Кременчуцький національний університет імені Михайла Остроградського, вул. Першотравнева, 20, м. Кременчук Полтавської обл., Україна, 39614. Тел. +38(097) 652-85-31. E-mail: 19bragasvetlana11@gmail.com

\section{Braha Svitlana Yuriivna.}

3rd year student, Psychology Profession, Kremenchuk Mykhailo Ostrohradskyi National University, vul. Pershotravneva, 20, Kremenchuk, Poltava Region, Ukraine, 39614.

Tel. +38(097) 652-85-31. E-mail: 19bragasvetlana11@gmail.com

\section{Citation (APA):}

Bilous, R., Valverde Cota, B., Braha, S. (2019). Sense of humor in process of decision-making among students. Engineering and Educational Technologies, 7 (2), 150-159. doi: https://doi.org/10.30929/2307-9770.2019.07.02.15

\section{Цитування (ДСТУ 8302:2015):}

Білоус Р. М., Валверде Кота Б., Брага С. Ю. Почуття гумору у процесі прийняття рішень студентами / Інженерні та освітні технології. 2019. Т. 7. № 2. С. 150-159. doi: https://doi.org/10.30929/2307-9770.2019.07.02.15

Обсяг статmі: $\quad$ сторінок - 10 ; умовних друк. аркушів - 1,448. 